\title{
ПОРІВНЯЛЬНІ СТУДІї
}

УДК 82.091

Віра ПРОСАЛОВА

д. філол. н., професор

Донецький національний університет

імені Василя Стуса

\section{ЛІТЕРАТУРНО-МАЛЯРСЬКІ КОРЕЛЯЦІЇ У НОВЕЛІСТИЦІ МИХАЙЛА ЯЦКОВА}

У статті застосовано інтермедіальний підхід до новелістики Михайла Яцкова. Цей підхід дає можливість виявити, як реалізувалася малярська складова в художньому мисленні автора. Акцентовано, що значний вплив на творче становлення письменника мали особисті знайомства з митцями, знання їхніх біографій, творчих доль. Звернено увагу на те, як у новелах письменника відбилася атмосфера суперництва між малярами, авторські симпатії й антипатії. Обгрунтовано, що прототипом образу Корнія Борсука 3 нарису «Смерть бога. Студія молотком» був Іван Труш, до якого письменник виявив негативне ставлення. Відзначено, що герої письменника для підтвердження своїх думок нерідко апелюють до живописних полотен, виявляють добре знання мистецьких раритетів. Обгрунтовано, що мистецька універсальність стала знаковою у XX столітті. 3'ясовано, що засвоєння М.Яцковом засобів суміжних мистецтв збагачувало зображально-виражальні можливості його художнього слова.

Ключові слова: мистецтво, література, живопис, кореляція, інтермедіальність, інтермедіальний підхід.

На межі XIX - початку XX століть мистецька універсальність стала знаковою: Обрі Бердслі реалізував себе як художник-графік, музикант і поет, Егон Шіле - як художник і поет, Жан Кокто - як письменник, художник i кінорежисер, Ернест Сетон-Томпсон - як письменник і художник, Альфред Кубін - як маляр і письменник, Казимир Малевич - як художник, поет i теоретик мистецтва, Михайло Матюшин - як маляр, музикант і теоретик мистецтва, Олексій Кручених - як маляр і поет. В українському науковомистецькому дискурсі межі століть універсальність обдарування виявили Іван Франко, Леся Українка, Володимир Винниченко, Агатангел Кримський, Богдан Лепкий, Юліан Панькевич, Михайло Жук, Іван Труш та багато інших діячів, які прагнули не відставати від віянь часу і реалізували свій творчий потенціал у різних сферах діяльності. 
Творчий потенціал Михайла Яцкова виявився в літературі, музиці, малярстві, інтенсивному засвоєнні автором властивих іншим видам мистецтва зображально-виражальних засобів. Трансляція елементів інших семіотичних систем, як, скажімо, малярства, скульптури, архітектури, дозволяла письменнику збагачувати можливості художнього слова, вербальними засобами досягати бажаної візуальності, пластичності. В літературних творах М.Яцків виявляв знання мистецьких раритетів (ідеться про образотворчі полотна, скульптурні ансамблі, музичні твори тощо), історії мистецтва, володіння такими різноманітними стилями, як імпресіонізм, експресіонізм, символізм, натуралізм, сюрреалізм. Поєднанням різних стильових ознак у літературному творі автор передавав розмаїття відчуттів, досягав бажаної поліфонії.

У художньому слові М.Яцків намагався «воскресити краску, пластику, тон, рух, ідею і ще щось більше» [11, с. 261]. За цим «більше» відкривався простір для відтворення того, що не піддавалося вербалізації, проте конче потребувало омовлення. Для опису природи, як переконував письменник, одного слова недостатньо. «При описах життя природи, - наголошував автор нарису «Смерть бога. Студія молотком», - треба персоніфікації руху, великого почуття малярства і музики; писане слово тут рветься, тріскає треба просто творити його, схоплювати комплекси красок, компонувати акорди...» [12, с. 56]. Як адепт синестезії, він стверджував, що «звуки не лише «понимати», але навіть занюхати можна» [12, с. 62].

Мета цієї статті - простежити, як Михайло Яцків здійснював презентацію малярських творів у літературних, визначити, якими засобами автор досягав ефекту візуальності в новелістиці. Насамперед обгрунтуємо доцільність осмислення цієї проблеми, що виявляється важливою як для усвідомлення шляхів збагачення художньої прози межі XIX - початку XX століть, так і розуміння авторської індивідуальності письменника, який, за власним зізнанням, «рвався до мистецтва»: в роки навчання в гімназії 
малював, під час перебування в театральній трупі пізнавав життя акторів, усе життя захоплювався грою відомих музикантів.

Мистецькі зацікавлення М.Яцкова не лишилися обійденими увагою літературознавців: Агнєшки Матусяк, Оксани Мельник, Миколи Ільницького, Олександра Рисака, Олександра Ткачука. Олександр Рисак, скажімо, зараховував прозаїка до митців «синкретичного світовідчуття» [9, с. 345], які завдяки засобам суміжних мистецтв творять свій неповторний художній світ. «Зображаючи персонажів-митців, Яцків не тільки виявляв модерністські тенденції, а й писав “символічну автобіографію”, - наголошувала Оксана Мельник. - Символістично-сецесійна настанова на свідомий синтез мистецтв, увага до мови в аспекті їі виражальності, декоративність, естетизм, домінування жіночих образів, пошуки в царині духовості й релігійності, інспірування проблематикою смерті, амбівалентність зображення поєднувалися в письменника 3 майже експресіоністичним використанням контрасту чорного й білого кольорів, вираженням межових станів людської психіки через мотив крику» [6, с. 19]. Стильовий синкретизм автора відзначила й Агнєшка Матусяк: «Яцкову - подібно до інших європейських письменників, які зверталися до імпресіоністичних засобів створення художнього світу - близькою була також романтична поетика 3 iï сенсуалізмом. Залишаючись у полі впливу такого типу тенденцій, український митець відчутно насичує свої твори символічними образами 3 багатозначним, асоціативним характером зображення, які становлять фундаментальний засіб його письменницької експресії» [5, с. 21]. В останні десятиліття увага до творчого доробку М.Яцкова пожвавилася, що підтверджують праці сучасних дослідників $[7,8,10]$, однак чимало аспектів індивідуальної манери письменника виявилися окресленими, проте не достатньою мірою проясненими, що надає особливої актуальності обраному аспекту аналізу.

Перебування письменника в мистецькому середовищі Львова, спілкування з молодомузівцями - композитором Станіславом Людкевичем, 
скрипалем-віртуозом, композитором i художником Іваном Косиніним, скульптором i малярем Михайлом Паращуком, a також знайомство 3 багатьма художниками - Антоном Манастирським, Іваном Северином, Юліаном Панькевичем, Теодором Вациком, Олексою Новаківським та іншими - давало Михайлу Яцкову багатий матеріал для творів. Атмосфера суперництва між митцями стимулювала його творчу діяльність, проте в мистецькому середовищі призводила до становлення культу найбільш спритних і практичних із них. Культ встановлювався, як правило, завдяки саморекламі, нерідко свідомому приниженні конкурентів, що викликало закономірне обурення в М.Яцкова, який не шкодував на адресу опонента різких натяків і нищівних характеристик: «новий Сава, руський мудрець 3 Бродів, предтеча нових, мудрих епігонів» [12, с. 88]; «Слава тому, що нічого не дав, а багато забрав і побиває того, що більше дав, ніж взяв!» [12, с. 80]. Автор наголошував, що його опонент, коли б «мав іти по трупі власного батька, то перейшов би без вагання» [12, с. 75]. Репрезентований Корнієм Борсуком із нарису «Смерть бога» тип «має тверді лікті», що допомагають йому прокладати шлях для себе і в мистецтві, і у критиці, і в інших сферах. Автор підкреслює, що родовід цих пристосуванців розпочинається від Ноя, врятованого Богом від потопу, отож, вони такі ж давні, як і людство.

Нарис «Смерть бога. Студія молотком» Михайло Яцків присвятив Юліану Панькевичу - художнику, автору сатиричних творів, казок та оповідань, перекладачу, справжньому ентузіасту розвитку рідної культури, одному 3 організаторів «Товариства для розвою руської штуки» (1898). Присвята цього нарису підтверджує шанобливе ставлення до митця, чиє полотно «Запорожець» протиставлялося «Хрещику» Івана Труша як вартісне примітивному. Ю.Панькевич також організовував хори, навчав молодь малярству, невтомно експериментував, уводячи народний колорит у релігійну тематику. Так, на полотні «Сільська мадонна» він, зокрема, відтворив сцену 3 життя галицького села без традиційних релігійних атрибутів, намалювавши молоду селянку у вишитій сорочці та червоній 
спідниці з маленьким хлопчиком, який довірливо тулиться до неї. Ця сцена відбивала авторське бачення жіночої краси та життєдайної материнської любові.

У нарисі «Смерть бога. Студія молотком» М.Яцків показав спроби героя відстоювати потребу освіти, виявив критичне ставлення до тих діячів культури, які не переймалися поліпшенням свого освітнього рівня. 3 цією метою автор художньо реконструював уявну полеміку митця і критика. Висловлювання Корнія Борсука про твори Данила Юрти будуються на основі цитат зі статей Івана Труша, що помітив ще Микола Свшан у рецензії на збірку «Чорні крила» і негативно оцінив авторську тенденційність, винісши вирок самому письменнику, який, на його думку, проголосив смерть не редакції народного органу, що друкував рецензії опонента, а самому собі. Публіцистичність не була органічною для стилю Михайла Яцкова, у пристрасній полеміці йому, очевидно, не завжди вдавалося погамувати емоції, що й позначилося на цьому нарисі, який, з одного боку, підтверджує мистецькі зацікавлення письменника, з іншого - різко негативне ставлення до тих діячів культури, які дбали про славу і достаток. «Борсука, як маляра, розреклямувала польська критика справді до неможливих границь, між вшехполяками мав він відчити, вони уважали його за naszego («нашого»)» [12 с. 59], - наголошує автор, реагуючи на способи рекламування мистецького доробку. Що ж до суперників, то в боротьбі за визнання ці митці всіляко їх очорнювали: «Слава тому, що не в силі сам сотворити нічого, а нищить, киринить, фальшує і курвить те, що другий сотворив!» [12, с. 79]. Ампліфікацією досягається експресивність висловлювання, передається сила почуттів.

У нарисі «Смерть бога. Студія молотком» згадується поет і маляр Людомир-Людвиг Бенедиктович, який брав участь у польському повстанні проти Російської імперії 1863 року, втратив обидві долоні, проте продовжував творчо працювати, а в 1912 році переїхав до Львова, що, очевидно, стало відомо М.Яцкову: «Було там описане дивно трагічне життя 
артиста Бенедиктовича, мистця великого стилю в відчуванню і відтворенні природи, який стратив в повстанню обі руки і малював в той спосіб, що жінка прив'язувала йому кисти до ліктя. Так в праці і поті здобував для себе і сім’ї кавалок насущного» [12, с. 74]. Велично-трагічне творче життя талановитого маляра протиставляється атмосфері нездорової конкуренції, що відбиває суспільно-політичні, соціальні, етнічні, морально-етичні проблеми всього суспільства.

У побудованому в формі дискусії 3 уявним опонентом нарисі осмислюються деталі з життя художника і критика Івана Труша. Описана у творі сцена пожежі і смерті дитини, чий закривавлений вигляд викликав у батька відразу, акцентується автором, щоб передати невідповідність між словами і діями опонента. Нарис Данила Юрти «Хлопчина - герой», що викликав негативну реакцію у Корнія Борсука, проектується на взаємини в родині. «Введення зовнішнього тексту в іманентний світ цього тексту дуже важливе, - наголошував Ю.Лотман. - 3 одного боку, у структурному смисловому полі тексту зовнішній текст трансформується, утворюючи нове повідомлення. Складність та багаторівневість компонентів, що беруть участь у текстовій взаємодії, призводить до відомої непередбачуваности тієї трансформації, якій піддається текст, що його уводимо. Але трансформується не тільки він - змінюється уся семіотична ситуація всередині текстового світу, до якого його вводять [4, с. 587]. Якщо в субтексті йшлося про альтруїзм героя, про те, що хлопець ціною власного життя прагнув помирити рідних, то в текстовому світі нарису - про зовсім протилежне: як закривавлене тіло мертвої дитини викликає відразу в рідного батька. «Текст у тексті», нарис у нарисі актуалізує проблему «митець і батько» і, відповідно, мало привабливі риси опонента.

У редагованому Іваном Трушем i Станіславом Людкевичем «Артистичному віснику» подавалися репродукції картин самого редактора, його силует, його афоризми, а для інших творців пластичного мистецтва майже не лишалося місця. Труш, як намагається переконати автор, свідомо у 
своїх мистецьких оглядах не згадував творів своїх конкурентів, зокрема Юліана Панькевича, тим самим демонструючи, що є цінності більшою мірою варті уваги, ніж його конкурентів.

М.Яцків розглядає копіювання предмета у творчому акті як нездатність знайти оригінальний підхід, звичайне ремісництво. На думку автора, І.Труш як художник відзначався здатністю копіювати, a не творити, тому i фотографував об’єкти для праці. «Я навіть хотів вірити в се, а нині виджу, що ти не творчий, композиційний дух, не артист, що схоплює невловимі тайни, лише сам фабрикував собі рекламу «кольориста»» [12, с. 68]. Йдеться не лише про проблему мімезису, а й опозицію реалізм/ модернізм, адже останній утверджував неміметичний спосіб художнього мислення.

Герої М.Яцкова нерідко послуговуються мистецькими артефактами для підтвердження своїх думок. Так, Данило Юрта, щоб переконати в неправомірності думки опонента, згадує скульптуру Людвіга ван Бетховена роботи німецького майстра Макса Клінгера. Скульптор зобразив великого композитора у вигляді олімпійського бога на багато оздобленому троні, 3 оголеним торсом, узутим у сандалії, у ніг митця він відтворив орла - символ Юпітера, творчої сили, висоти духу, звільнення від пут, що не здатні, проте, скувати творчий дух майстра. Скульптура Бетховена виготовлена $з$ різного матеріалу, отож, наочно підтверджує свободу митця у виборі засобів реалізації творчого задуму.

Як добрий знавець живопису письменник актуалізував у пам’яті читача смисл образотворчих полотен, удавався до алюзій, щоб змусити реципієнта згадати відому картину («Був се його улюблений образ: Наполеон по битві під Ватерлоо» [11, с. 431]). Знання історії живопису дозволило апелювати до життєпису відомих малярів, як, скажімо, Артура Іроттґера, який, на думку автора, користувався незаслуженою популярністю в поляків, що, очевидно, пояснюється історією трагічного кохання хворого на сухоти художника до юної Ванди Монне. Експліцитна чи імпліцитна (завдяки асоціаціям, алюзіям) актуалізація імен багатьох малярів (французів Франсуа Буше і Жана Грега, 
англійських прерафаелітів, норвезького Едварда Мунка, англійця Данте Габрієля Россетті, німця Матіса Нітхардта) підтверджувала ерудицію письменника.

М.Яцків художньо відтворює особливості різних видів мистецтва, акцентує неспроможність малярськими засобами відтворити слухові враження. Зовнішність співака, схиленого над кобзою без струн, у новелі «Портрет» символізує нездатність засобами малярства передати чарівний спів.

У відтворенні зовнішності героїв М.Яцків буває ощадливим, що досягається шляхом апеляції до відомих у світовій культурі артефактів: «В лиці Ничаєнка замерз спокій, темне волосся спадало на плечі, голова Антіноя» [11, с. 139]. Згадкою про улюбленця римського імператора Адріана - символу краси і безсмертя - долучаються зорові асоціації. Ніна Дмитрієва помітила, що «інколи вміння письменника побачити, зримо представити те, про що він пише, проявляється у його творі приховано, підспудно, не виявляючись прямо, але надаючи особливої переконливості його словам» [2, c. 15]. Як у цьому випадку, коли в уяві реципієнта постає дивовижний красень.

Щоб передати зміни, що відбувалися в душевному стані героїв, художник змушений малювати низку портретів, письменник же може передати цю динаміку вербальними засобами в одному творі. М. Яцків користувався перевагами літератури, відтворюючи, як митець помічає, скажімо, зміни в зовнішності своєї дівчини-музи: «В тій дівчині замічав Даріан все дві постаті. Коли приходила до нього, була старша і сувора, а коли пригорнув їі до себе, личко ставало дрібне, дівоче, з рожевим відтінком. Раз оріхові брови, то знов уста краски суниці впадали під увагу» [11, с. 128]. Як маляр, він передав відтінки барв, актуалізуючи колір то горіха, то достиглої суниці тощо.

У зображенні жіночої вроди виразно виявляється індивідуальна манера автора, який підкреслює, що зустріч з ідеалом красивої жінки можлива 
завдяки творчій уяві митця, який наділяє їі зовнішність своїми жаданнями і сподіваннями. Слів у цьому випадку недостатньо, щоб передати досконалість героїні: «Коли б я назвав Тебе рожею, то се був би лиш символ твоїх уст, символ краси, яка скоро в’яне. Коли б я назвав Тебе пташиною, то виявив би лиш одну струну Твоєї душі, ніжний спів. Коли б я назвав Тебе зіркою, то се було би слово лиш про Твоє око як самітнє світло в просторі. Коли б я назвав Тебе людиною, то се була би раз химерна дитина, то знов терпіння й молодеча туга» $[11$, с. 128]. У цьому випадку йдеться не про об'єктивний опис зовнішності Ілони, а насамперед про суб'єктивне враження, яке вона викликала у скульптора 3 «Архітвору». Як і Россеті, автор наділяє героїню тими ознаками, які відшукує в ній митець. Словесний портрет героїні, введений у пейзажну замальовку, акцентує іiі природність. Подані через сприйняття митця ці портрети відбивають його уявлення про красу, стан натхнення, зумовленого спогляданням омріяного ідеалу.

М. Яцків володів багатою палітрою зображально-виражальних засобів. Зовнішню красу жінок нерідко передавав за допомогою порівнянь із квітами («твоє личко - біла лілея...», «біліла, як лілея на чорнім коврі»), деревами («вона, як струнка берізка», «струнка, як ялиця»), птахами («груди - пара білих голубів»). Порівнянням жінки 3 лотосом, лілією, трояндою акцентувалася іiі чистота, досконалість, незайманість. Незвичні порівняння відбивали насамперед особливості сприйняття та внутрішній світ героїнь, їх душевний стан.

Микола Ільницький звернув увагу на те, що М.Яцків «запозичив із живопису принцип композиційної структури» [3, с. 22], різні ракурси відтворення образів. Якщо малярі мусили створювати низку портретів 3 однієї натурниці в різних позах, ракурсах, освітленні, то письменник подає портрет героїні то у профіль («Профіль Ілони нагадував божу дівчину візантійського маляра» [11, с. 127]), то в анфас, удень і при світлі місяця, що надає виразу обличчя зовсім інших ознак. «Крізь дерева падав на личко мертвий промінь місяця, в тіні чорніли ями іiі очей, з чола спливала синя 
пляма. Даріан вдивився, причарований грозою тайни: зі споду ями блиснув крайчик ока» [11, с. 129]. Те, що лишалося неосвітленим, перетворювалося в темні плями, набувало нечітких обрисів і ознак таємничості.

Для М.Яцкова-художника світло мало важливе значення, адже воно вихоплювало 3 темряви постаті людей, риси їхнього обличчя, сприяло досягненню кольорового контрасту, переважно чорно-білого. Недостатність сонячного світла, навпаки, збуджувала уяву, призводила до виникнення несподіваних візуальних ефектів: «Галєрія образів на стінах почала гарцювати, якби збиралася до скаженого танцю» $[11$, с.78]. Малюнки несподівано ожили в уяві переляканого героя, отож, ідеться про суб’єктивне відтворення візуальних вражень.

Як і малярі, М.Яцків удається до прийому композиційного обрамлення. Криваво-червона гама служить у новелі «Благословення» рамкою тексту, обрамленням усього життя родини: «Кров’ю пливе осінній захід крізь шпитальне вікно на розп’ятого Христа» [11, с. 96]; «Криваве сонце притьмило червону лямку в ногах Христа, обагрило всьо довкола і ген-ген далекий осінній світ» [11, с. 97]. У межах обрамленого тексту вимальовується історія безпросвітного життя однієї родини: «...В ухах шум: нужда-нужда-нужда і нудьга, як море. Хвиля за хвилею жене - не здогонить i гуде: суєта-суєта-суєта...» [11, с. 96]. Завдяки музичному супроводу, акцентуванні ключових слів, фонічній виразності поглиблюється сугестивний вплив розповіді хворої жінки на читача.

М.Яцків продемонстрував у творах візуальне сприйняття світу, передаючи багату кольорову гаму, контури жіночого тіла, вдаючись до порівнянь, що виникли на основі зорових вражень. Малярська складова в художньому мисленні письменника виявилася в живописанні словом, відтворенні вражень від образотворчих полотен, акцентуванні чорно-білих барв. Твори М. Яцкова, що актуалізують образотворчі полотна, складають своєрідну художню галерею, що словесно репрезентує доробок майстрів різних епох: прерафаелітів, експресіоністів, символістів. 


\section{ЛІТЕРАТУРА}

1. Вайсштайн У. Взаємовисвітлення літератури та музики: сфера компаративістики? / Ульріх Вайсштайн // Сучасна літературна компаративістика: стратегії і методи. Антологія / За заг. ред. Дмитра Наливайка. - К.: Вид. дім „Києво-Могилянська академія", 2009. - С. 391-410.

2. Дмитриева Н. А. Изображение и слово / Нина Александровна Дмитриева. - М.: Искусство, 1962. - 244 с.

3. Ільницький М. «Поетична концепція з музичним і малярським тлом...»[Текст] / Микола Ільницький // Яцків М. Муза на чорному коні. Оповідання і новели. Повісті. Спогади і статті. - К.: Дніпро, 1989. - С. 5-28.

4. Лотман Ю. Текст у тексті / Юрій Лотман // Антологія світової літературнокритичної думки XX ст. / За ред. Марії Зубрицької. 2-е вид., доповнене. - Львів: Літопис, 2001. - C. 581-595.

5. Матусяк А. Химерний Яцків : Модерністський дискурс у прозі Михайла Яцкова [Текст] / Агнєшка Матусяк. - Вроцлав ; Львів : ЛА «Піраміда», 2010. - 234 с.

6. Мельник О. Модерністський феномен Михайла Яцкова: канон та інтерпретація : автореферат дисертації на здоб. наукового ступеня кандидата філологічних наук / Львівський національний університет ім. І.Франка. - Львів, 2009. - 20 с.

7. Мельник О. Модерністський феномен Михайла Яцкова: канон та інтерпретація / НАН України, Інститут Івана Франка. - Київ: Наукова думка, 2011. - 295 с. - (Проект «Наукова книга» (Молоді вчені).

8. Просалова В. А. Літературно-музичні кореляції в малій прозі М.Яцкова // Філологічний дискурс : зб. наук. праць / гол. ред. Віталій Мацько. - Хмельницький: ХГПА, 2016. - Вип. 3. - С. 126-138.

9. Рисак О. Деякі проблеми поетики і стилю Михайла Яцківа [Текст] / Олександр Рисак // Рисак О. Найперше - музика у слові: Проблема синтезу мистецтв в українській літературі кінця XIX - початку XX століття. - Луцьк, 1999. - С. 345- 354.

10. Ткачук Олександр. Наративні принципи прози Михайла Яцківа : монографія / Олександр Ткачук. - Тернопіль, 2013. - 275 с.

11. Яцків М. Ю. Муза на чорному коні : Оповідання і новели. Повісті. Спогади і статті [Текст] / М. Ю. Яцків ; упоряд., авт. передм. та приміт. М.М. Ільницький. - К. : Дніпро, 1989. - 846 с.

12. Яцків М. Смерть бога. Нариси й новелі / Михайло Яцків. - Львів: Новітня бібліотека, 1913. - Ч. 13-14. - 98 с.

\section{REFERENCES}

1. Weisstein U. Vzayemovysvitlennya literatury ta muzyky: sfera komparatyvistyky? [Mutual coverage of literature and music: the scope of comparative?], Suchasna literaturna komparatyvistyka: stratehiyi i metody. Antolohiya [Modern literary comparative: strategies and methods. Anthology], Kyiv, Vyd. dim «Kyyevo-Mohylyans'ka akademiya», 2009, pp. 391-410 [In Ukrainian].

2. Dmitrieva N. A. Izobrazhenie i slovo [Image and word], Moskva, Iskusstvo, 1962, 244 $\mathrm{p}$ [In Russian].

3. Il'nyts'kyy $M$. «Poetychna kontseptsiya z muzychnym i malyars'kym tlom...» [«Poetic concept of background music and painting»], M. Yatskiv Muza na chornomu koni. Opovidannya $i$ novely. Povisti. Spohady i statti [M. Yatskiv. The Muse on a Black Horse: Stories and novels. Memoires and articles], Kyiv, Dnipro, 1989, pp. 5-28 [In Ukrainian].

4. Lotman $Y u$. Tekst $\mathrm{u}$ teksti [Text in the text], Antolohiya svitovoyi literaturnokrytychnoyi dumky XX st. [The Anthology of the world literary criticism], L'viv, Litopys, 2001, pp. 581-595 [In Ukrainian]. 
5. Matusiak A. Khymernyy Yatskiv: Modernist·s'kyy dyskurs u prozi Mykhayla Yatskova [Chimerical Yatskiv: Modern discourse in the Mykhaylo Yatskiv's prose], Wroclaw, L'viv, LA «Piramida», 2010, 234 p [In Ukrainian].

6. Mel'nyk $O$. Modernist·s'kyy fenomen Mykhayla Yatskova: kanon ta interpretatsiya: avtoreferat dysertatsiyi na zdob. naukovoho stupenya kandydata filolohichnykh nauk [The phenomenon of Mykhaylo Yatskiv's modernism: the canon and interpretation: thesis of $\mathrm{PhD}$ work in philology], L'viv, L'vivs'kyy natsional'nyy universytet im. I. Franka, 2009, 20 p [In Ukrainian].

7. Mel'nyk $O$. Modernist·s'kyy fenomen Mykhayla Yatskova: kanon ta interpretatsiya [The phenomenon of Mykhaylo Yatskiv's modernism: the canon and interpretation], Kyiv, Naukova dumka, 2011, 295 p [In Ukrainian].

8. Prosalova V. A. Literaturno-muzychni korelyatsiyi v maliy prozi M.Yatskova [Literary-music correlations in the small prose of M. Yatskov], Filolohichnyy dyskurs : zb. nauk.

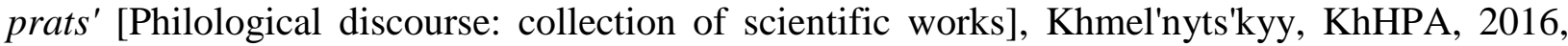
Vol. 23, pp. 126-138 [In Ukrainian].

9. Rysak $O$. Deyaki problemy poetyky i stylyu Mykhayla Yatskiva [Some problems of Mykhaylo Yatskiv's poetics and style], Naypershe - muzyka u slovi: Problema syntezu mystetstv $v$ ukrayins'kiy literaturi kintsya XIX - pochatku XX stolittya [At first - the music in the word: problem of art's synthesis in Ukrainian literature of the end of XIX - beginning of XX century], Luts'k, 1999, pp. 345-354 [In Ukrainian].

10. Tkachuk $O$. Naratyvni pryntsypy prozy Mykhayla Yatskiva : monohrafiya [Principles of narration in the Mykhaylo Yatskiv's prose: the monograph], Ternopil', 2013, $275 \mathrm{p}$ [In Ukrainian].

11. Yatskiv M. Yu. Muza na chornomu koni: Opovidannya i novely. Povisti. Spohady i statti [The Muse on a Black Horse: Stories and novels. Memoires and articles], Kyiv, Dnipro, 1989, 846 p [In Ukrainian].

12. Yatskiv M. Smert' boha. Narysy y noveli [Death of the God: Essays and novelles], L'viv: Novitnya biblioteka, 1913, Ch. 13-14, 98 p [In Ukrainian].

\section{АННОТАЦИЯ}

\section{Вера Просалова. Литературно-живописные корреляции в новеллистике Михаила} Яцкова

В статье использован интермедиальный подход к творчеству Михаила Яцкова, благодаря ему выявлены многочисленные литературно-живописные корреляции в произведениях писателя, которые подтверждают хорошее знание автором истории искусства, творческих биографий художников разных времён и народов: Людомира-Людвига Бенедиктовича, Артура Гроттгера, Ивана Труша, Юлиана Панькевича, Обри Бердсли и других.

В статье определены средства достижения визуального эффекта в произведениях прозаика, функция интермедиальных вкраплений, подтверждающих разнообразие авторских интересов: от эпохи Античности - до новейших течений и тенденций в искусстве.

Ключевые слова: искусство, литература, живопись, корреляция, интермедиальность, интермедиальный подход.

\footnotetext{
ABSTRACT

Vira Prosalova. Literary and painting correlation in the short stories by Mykhailo Yatskov The intermedial approach to Michael Yatskov's short stories is used in the paper. This approach makes it possible to reveal how the part of painting is embodied in the author's artistic thinking. It is emphasized that personal encounters with artists, knowledge of their biographies, creative lives have had significant influence on the creative formation of the writer.

Attention is paid to the way how the atmosphere of rivalry between painters, authors' sympathies and antipathies are reflected in the writer's novels. It is proved that Ivan Trush was the prototype
} 
of Korney Barsuk's image in the essay "Death of God. Studio with hammer", and he was marked by the author's negative attitude. The characters often refer to the paintings for confirming their thoughts and demonstrate good knowledge of art rarities.

The article reveals the means to achieve the visual effect in the writer's works, the function of intermedial inclusions that confirm diversity of author's interests: from Antiquity era - to the latest trends and tendencies in art. Numerous literary and painting correlations in the novels of the author confirm good knowledge of art history, creative biographies of the painters of different times and peoples: Lyudomyr-Lyudvyg Benedyktovych, Artur Grottger, Ivan Trush, Julian Pankevych, Aubrey Beardsley, Nithardta Mathis and others.

It is proved that artistic versatility has become a landmark in the twentieth century. It is determined that figurative-expressive possibilities of M. Yatskov's artistic expression have been enlarged with his mastering the assets of related arts.

Key words: art, literature, painting, correlation, intermediality, intermedial approach. 